\title{
Function of space in Daniel 1
}

\begin{abstract}
Author:
Marius $\mathrm{Nel}^{1}$

Affiliation:

${ }^{1}$ Faculty of Theology,

North-West University,

Potchefstroom Campus,

South Africa

Correspondence to:

Marius Nel

Email:

nel.marius1@gmail.com

Postal address:

PO Box 12373, Bendor Park

0713, South Africa

Dates:

Received: 05 Nov. 2013

Accepted: 30 Jan. 2014

Published: 06 June 2014

How to cite this article: Nel, M., 2014, 'Function of space in Daniel 1', In die Skriflig/In Luce Verbi 48(2), Art. \#1778, 7 pages. http:// dx.doi.org/10.4102/ids. v48i2.1778
\end{abstract}

\section{Copyright:}

(C) 2014. The Authors.

Licensee: AOSIS OpenJournals. This work

is licensed under the Creative Commons

Attribution License.
Read online:
Daniel 1 narrates how Daniel and his friends come from Jerusalem and are appointed as officials at the royal court in Babylon. The narrative is governed by the various and significant references to space. The Jews' loyalty towards Jerusalem and its association with the Temple and temple cult is challenged by the loyalty required from them at the Babylonian court as symbolised by the new names they receive - names associated with the Babylonian gods. The strategy they devise to retain their loyalty towards $\mathrm{YHWH}$ is decided by their request for a specific specific type of food. Their eating special food in contrast to the royal food set apart for the candidates, creates a space that relates to the determinative contrast between Jerusalem and Shinar. The tale in Daniel 1 is determined by references to space that allowed the Jewish readers to understand its meaning.

Die funksie van ruimte in Daniël 1. Daniël 1 vertel hoe Daniël en sy vriende uit Jerusalem as hofamptenare in Babilon aangestel word. Die narratief word beheers deur verskeie belangrike verwysings na ruimte. Die Joodse jongmanne se lojaliteit aan Jerusalem en hulle verbintenis met die Tempel en tempelkultus, word deur die lojaliteit wat aan die koninklike hof van hulle verwag word, getoets. Dit word deur die nuwe name wat aan hulle gegee is, gedemonstreer - name wat waarskynlik met Babiloniese gode se name verband hou. Hulle strategie om aan JHWH lojaal te bly, berus op hulle versoek om 'n spesifieke soort voedsel te gebruik. Afsonderlike voedsel in teenstelling met dié van die koning, skep die ruimte waarbinne die bepalende kontras tussen Jerusalem en Sinar gehandhaaf kan word. Die vertelling in Daniël 1 word bepaal deur verwysings na ruimte, wat die Joodse leser in staat stel om die betekenis daarvan te begryp.

\section{Introduction}

Narratives necessarily happen in a space, and space forms part of the ideological characteristics of narratives. A good narrative utilises space in an effective way to enrich the narrative and serve its ideological meaning. In this article, reconstruction of ancient space is used to indicate how space determines and serves the socio-historic background and ideology of the composition of Daniel 1. The issue of space is treated in different ways in the narrative and the following dimensions can be observed:

- A spatio-religious dimension, with the binary spaces of Judah-Babylon and Jerusalem-Shinar playing an ideological role.

- A social association of space, with the situation of deportation placed contra the royal court with its riches and splendor.

- A religio-spatial distancing between Israel's and Babylon's religion, and Israel's God and Babylon's god.

- A wisdom dimension, where loyalty towards God results in the gift of political ingenuity to explicate dreams, visions and apparitions, prediction of the future by way of astrology, and the interpretation of signs and omens as well as political acumen to advise a ruler or to rule.

Space is utilised by the narrator to demonstrate the power play behind the narrative: between Judah as a defeated nation and mighty Babylon, the Jewish king in the prison in Babylon and the king ruling over his royal court, Israel's God (who was seemingly defeated when his country was taken and his people removed from it) and Babylon's god.

\section{Daniel 1 and space \\ Daniel 1:1-2: Jerusalem and Shinar}

The narrative in Daniel 1 relates how Daniel and his three friends, of royal or noble descent, ended up at the Babylonian court, because they qualified in terms of the king's requirements: they were 
without physical defect, of good appearance, versed in every branch of wisdom, well-informed, and discerning - thus considered suitable for service at the royal court (Dn 1:4).

Daniel 1 starts and finishes with a spatial-temporal orientation and places two significant spaces purposefully in contrast to each other: Jerusalem and Babel (Dn 1:1-2). In this way the characters in the book are placed against a historical background of the exile of Judahites to Babylon - even though Jehoiakim was never taken to Babylon. ${ }^{1}$ The narrator creates the impression that Daniel experienced the comprehensive reformation initiated by King Josiah during the time when Jeremiah proclaimed a message of doom for his people (Anderson 1975:15). ${ }^{2}$ Josiah's birth coincided with the rise of the neo-Babylonian empire when the Chaldeans and Medes cooperated to conquer the Assyrian empire and destroyed Nineveh. The four friends were supposed to have been deported to Babylon at the end of 605 BCE, when their kingdom was reduced to a vassal state of Babylon (Burden 1993:1223). The purpose of the historical placing of the narrative is to explain how Jews ended up in Babylon, and the temple utensils in the temple of Marduk.

Even though Jerusalem is only mentioned in Daniel 1:1, it stands over against Babylon for the rest of the narrative, because the narrator links Jerusalem to the Jewish religious cult (Dn 1:2 mentions that the vessels belonging to the Temple of God are given into the hand of the king of Babylon) and Daniel's decision to refuse the royal food has a cultic connotation. Israel viewed Jerusalem, the temple and Mount Zion as extensions of YHWH's god-space, whilst the land of Israel was accepted as a holy land that fell directly under the rule of YHWH (De Bruyn 2014:9). According to the discipline of critical spatiality 'Jerusalem and the sanctuary are not mere physical entities, but indicate a mental, sociological, theological space created' (Venter 2004:619). The territory beyond the borders of Israel was demarcated as heathen or profane and Babylonia serves as one of the important symbols for this world. The space of Babylon is to be understood in terms of continuation of the life of Judah (Venter 2006:994). 'The old story world sets the new story world in relief. Homeland gives way to alien land' (Fewell 1988:34). ${ }^{3}$

Jerusalem serves as a symbol of Judah's religion in the perception of the narrator. ${ }^{4}$ 'Jerusalem and its sanctuary

1.Daniel $1: 2$ is probably corrupt as Charles (1929:6) already acknowledged and as shown by the Greek translation. He opines that it read: 'And Adonai gave Jehoiakim the utensils of the house of God to the land of Shinar, but the utensils he brought to the treasure house of his god.' A scribe, copying the text, left out the words in italics, probably due to homoioteleuton. The words are, however, necessary to understand probably due to homoioteleuton. The words are, however, necessary to understand
verse 3 . Modern translations accept that the subject refers to the temple utensils verse 3 . Modern translations accept that the subject refers to the temple utensils -
cf. the Jerusalem Bible version: 'He took them away to the land of Shinar, and stored the sacred vessels in the treasury of his own gods.

2.Cf. Josephus' remark in Antiquities X:10.1 that Daniel and his three friends were descendants of King Zedekiah.

3.Cognitive linguistics emphasises that words denote or symbolise concepts. The concept of 'space' forms an integral part of human cognition and, together with 'time', defines one of the most important basic conceptual domains of human thinking. Humans use 'space' to make sense of the world around them and thus space forms an integral part of the way in which they express themselves. All human behaviour is located in and constructed of space (De Bruyn 2014:2-3, referring to Haspelmath 1997; Zlatev 2007; Low \& Lawrence-Zuniga 2003).

4.A symbol plays a specific role, as defined by Wouk (1959:67): 'If its meaning can be neatly exposed like the parts of a machine or the solution of a detective novel, then a symbol lacks the poetry by which symbols live. play a central role in the theological conceptualisation of the Daniel Trägerkreise' (Venter 2004:620). Priestly circles conceived the temple as the holy place of the people of Israel, but also the holy centre of all creation (Sweeney 2001:135) - a cosmic institution in which temple and world were considered 'congeneric' (Levenson 1984:286). For this reason, YHWH gives the 'king of Judah', 'Jerusalem' and 'the vessels

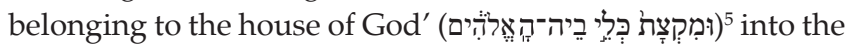
hands of the king of Babylon, who puts the vessels into the

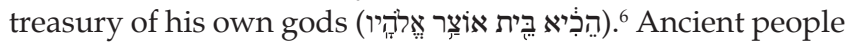
believed that each deity had an own region or territory in which they exerted power and authority. ${ }^{7}$ In battle, each nation summoned their gods to protect them and when they lost a battle, it was believed that the gods were not strong enough to protect them. These gods and their territory of authority were then subjected to the authority of the victor's gods, as Psalm 137 indicates (Hossfeld \& Zenger 2008:694). In Daniel 1, YHWH's authority is challenged by an invasion of his god-space (De Bruyn 2014:11).

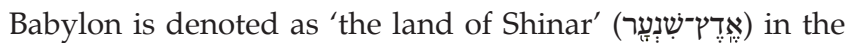
Masoretic text (translated 'to Babylonia' in the Septuagint). The reference is to the narrative in Genesis 11, where the people of the earth moved eastwards when they found a valley in the land of Shinar where they settled and built a city and tower. The purpose of the tower, with its top reaching heaven, was to 'make a name for ourselves, so that we do not get scattered all over the world' (Gn 11:4). The enterprise ends with YHWH ironically having to come down to see the city and tower, and confusing their language so that they could not understand each other (Gn 11:8). The people were thus scattered all over the world in different language groups, and the city is called Babel - from the root bll [to confuse], although 'Babel' actually means 'gate of the god' (Wansbrough 1985:29). 'Shinar' is an old name for Babylonia also found in Genesis 10:10 and 14:1, 9 (Lucas 2002:52). The archaic term is used purposefully to call up associations for the readers: Shinar is the country connected to Nimrod, a mighty hunter in the eyes of $\mathrm{YHWH}$ and 'the first potentate on earth' (Gn 10:8). As the country of Babel, it is associated with hubris and evil - themes frequently exploited in apocalyptic literature of the inter-testamental period. Zechariah 5:5-11

5. Koehler and Baumgartner (1958:849) derives miktsat from ketsai - utilised here in terms of a part of, or some of (as in Neh 7:69). The verb sounds like qēs, the term for 'end' - an important theological term borrowed from the prophets, starting in Amos $8: 2$ and utilised in the apocalyptic eschatology, which is also found in the visions of the the Book of Daniel (Dn 2, 7-12) to refer to the 'end time' (Wagner 1997:1155). The emphasis is on Adonai giving Judah and its king into the hand of the king of Babylon. The tales (Dn 1-6) demonstrate his sovereignty in different contexts. Compare describing Nebuchadnezzar as the servant of YHWH, whils saiah 47:6 emphasises his cruelty towards Israel. Daniel 4:34, 37 describes how the king of Babylon bows the knee before YHWH.

6.The words 'to the house of his god' look like dittography (a repetition due to a mistake made by a later scribe) and the words are left out by most modern translators. The words are also left out by the Greek translations. However, if the author's love of repetition is taken into account, the words can rather be seen as an intentional and deliberate effort by the narrator to emphasise that the place where the temple vessels are taken is in Babylon, in the temple of the god of the place of exile. The god refers to Marduk or Bel - the god of the state and chief god of the Babylonian pantheon (Helberg 1994:22; Abusch 1995). Bel is an Akkadian word meaning "lord" or 'master'. It is similar on grammatical grounds to Old Semitic Baal. Bel is the name or "master. It is similar on grammatical grounds to Old Semitic Baal. Bel is the name of the god responsible for the creation of the world and his partner is Belet, the mother goddess. Eventually, Bel was overshadowed by Marduk and in the end the
two were identified with each other (Van Reeth 1994:41; Kühlewein 1997:247).

7.Compare De Bruyn's (2014:8) reference to an alternative reading of Deuteronomy $32: 8-9$ : that the peoples of the earth were given its own territory according to the number of the gods. 
describes Shinar as a woman sitting in the measuring basket called Wickedness, taken to Shinar where she will be housed. Babel is a symbol of humankind's best efforts to establish an earthly paradise (Hammer 1976:18). The city was built on the banks of the Euphrates, approximately 80 kilometers from modern day Bagdad. ${ }^{8}$ Babel is a symbol of injustice and punishment for Jews, as depicted in Jeremiah 40 and Isaiah $13,{ }^{9}$ due to its association with the exile of Judah. ${ }^{10}$

The narrator uses the temporal-spatial placing of the narrative effectively to indicate where and when the narrative takes place, but also to create a creative contrast between two spaces in order to explain Daniel and his three friends' loyalty, which forms a major theme in the first chapter. The narrative is about a struggle between Nebuchadnezzar and all that he stands for, and the four Jews and their loyalty towards the God of Israel, described in terms of their choice of food. The foreign space of Babylon requires the exilic Jews to adapt to new circumstances, whilst at the same time prevent becoming absorbed in the customs and religion of Babylon (Venter 2006:994): 'A specific immunity had to be maintained without withdrawing from the reality of the new circumstances.' The tales in Daniel (Humphreys 1973):

\begin{abstract}
... present a style of life for the diaspora Jew which affirms most strongly that at one and the same time the Jew can remain loyal to his heritage and God and yet can live a creative, rewarding, and fulfilled life precisely within a foreign setting, and in interaction with it. (p. 223)
\end{abstract}

The viewpoint of the narrator arranges spatial references in such a way that a dynamic originates in the first tale and becomes even more prominent in the following tales. The contest in Daniel 1 is not between Nebuchadnezzar and his god on the one side, and Jehoiakim and his God on the other side. Two of the characters, Jehoiakim and Nebuchadnezzar's god, fade in the background and die for all practical reasons in the tale with Nebuchadnezzar and the narrator's God coming to the fore as the only two characters surviving the tale. The narrator's God is characterised by Jerusalem and all it stands for, whilst Nebuchadnezzar is associated with the land of Shinar and all the negative associations it carries for the narrator's readers. In this way, the narrator's perspective is enforced on the tale, with the narrator bringing Adonai's power and acts in relation to Nebuchadnezzar's activities. This constructs a world where the Jewish God rules sovereignly - where he determines what happens on earth, even in hostile territories. Even the acts of foreign rulers

8.References to Shinar are found in Genesis 10:10, 11:2, 14:1, 9 Joshua 7:21, Isaiah $11: 11$, Zechariah $5: 11$ and Daniel $1: 2$. Isaiah $14: 4,8$ and $22-23$ tell how the king of $11: 11$, Zechariah $5: 11$ and Daniel $1: 2$. Isaiah $14: 4,8$ and $22-23$ tell how the king of
Babylon will be punished by God, and verses 13 to 14 have apocalyptic undertones.

9.Isaiah describes the Babylonian army: 'They come from a distant land, from the end of the heavens, the LORD and the weapons of his indignation, to destroy the whole earth. Wail, for the day of the LORD is near; as destruction from the Almighty it will come!' (Is 13:5-6). Their occupation of Judah is described in terms of the coming of the day of YHWH: ' $[\mathrm{C}]$ ruel, with wrath and fierce anger, to make the earth a desolation and to destroy its sinners from it. For the stars of the heavens and their constellations will not give their light; the sun will be dark at its rising and the moon will not shed its light' (Is 13:9-10).

10.In the New Testament, the connotation of Babylon with injustice and punishment is taken up: 'The woman was arrayed in purple and scarlet, and bedecked with gold and jewels and peall, holding in her hand a golden cup full of abomination ( mystery: "Babylon the great, mother of harlots and of earth's abominations." And I saw the woman, drunk with the blood of the saints and the blood of the martyrs of Jesus' (Rv 17:4-6) are determined by him. The narrator creates this world by mentioning Adonai as the determinative factor in one of the most decisive events in Israel's history, the Babylonian exile (Fewell 1991:15).

\section{Daniel 1:3-7: Working at the royal court}

The royal descendants and other nobles exiled from their country were given preferential treatment. They were deported first, whilst the poor peasants were left behind (2 Ki 24:24; 25:12). Potential candidates for the royal court were recruited from this group. They had to be royal descendants without blemish, handsome, proficient in wisdom, knowledgeable and intelligent, and capable of serving in the royal palace (Dn 1:3-4). ${ }^{11}$ Their training is described as 'teaching them the writings and the language of the Chaldeans' (Dn 1:4) - meaningful terms denoting introduction to Babylonian religion with its preference for magical arts, astrology and sorcery, as confirmed by the comparison in verse 20 between the Jewish wise men

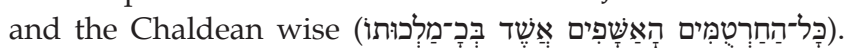
Chaldean wisdom carried the connotation of magic due to its connection with the Chaldeans, referring to tribes from Kaldu, but in 10 out of 12 times the term is used, it refers to predictors of the future (Davies 1985:38). The Chaldeans were the magicians, exorcists and sorcerers that Daniel 2:2 refers to - the intellectual elite of Babylon (Helberg 1994:23). The Chaldean language, referring to the neo-Babylonian court language or the Sumerian language with its highly complicated cuneiform was the gateway to the omen texts and texts containing holy myths and rituals of Babylonian religion underlying the political system. In learning the language, the Jews are not only exposed to this ideology, but they also acknowledge its power. The education of the Jewish young men were nothing else than a re-education in the Babylonian culture (Burden 1993:1223), with religion forming an indispensable part of Babylonian culture. This entails a 'rite of passage' in Fewell's (1988:38) terms - a ritual designed to facilitate people's passing from one phase of life into another. The first step in this process was to separate the persons from their community and seclude them. Then they experience a liminal existence in which they were taught special knowledge that would enable them to function in the new roles they would be assuming. They were encouraged to suppress their formed allegiances in elevation of their new allegiances. If successful, this process would lead them to adopt a new identity and a change of being. In the last stage of the passage, they were reintegrated into the new society (Fewell 1988:38). As (Venter 2006) explained:

In conflict with their upbringing and religious belief, they were to become magicians and enchanters at a foreign court. They were to be educated in the Babylonian culture, its specific language and its ideology of the esoteric. (p. 993)

Awarding new names to the four friends was an important element of the rite of passage. The new names carried elements of the names of Babylonian gods. The process of

11.As in the JPS Tanakh translation (1985; 1999) 
name change denotes deculturisation and denationalisation (Nomen est omen). ${ }^{12}$ A new name indicates a new life, and the power to change someone's name implies one's power over that person (cp. Gn 41:45; 2 Ki 23:34; 2 Ki 24:17). The theophoric names (Daniel - God is my judge; Hananiah - YHWH is gracious; Mishael - who is like God; Azariah - YHWH has helped) became names with a relation to Babylonian gods, although researchers do not agree to what extent (Keil 1975:79; Anderson 1984:37; Ward \& Ward 1995:27). ${ }^{13}$ Fewell's suggestion (1991:137) that the names presented a perversion of the names of the Babylonian gods, Bel, Marduk and Nebo, is provocative and shows how the narrator may be sharing a joke with the readers behind the back of the Babylonian tyrants, although modern readers are left in the dark due to their limited knowledge of the Hebrew language and background. The first readers would have enjoyed the irony of the situation, carried further in the narration of the food.

The four friends successfully underwent the rite of passage and became an integral part of the Babylonian court, although they corroborated their original national identity. Their dual citizenship formed in the liminal phase was due to the specific measures Daniel took with regard to the assignment of food to the court candidates (Venter 2006:996).

\section{Daniel 1:8-16: Food and defiling}

In the situation of exile in Babylon, it was 'self-evident' that the Babylonian gods had triumphed, that Yahweh had failed, either because of weakness or because of indifference. Either way, the evidence suggested that loyalty to Yahweh no longer worked or was worth practicing, because other powers could give more reliable and immediate payoffs. (Brueggemann 1997:20)

Daniel resolved not to defile himself with the king's food לָאָגתי indicates that he had a cultic problem with the food, related to the Mosaic laws regulating clean and unclean foods (Clarke 1967:692). Strict observance of laws related to food has proven through the centuries an effective means to distinguish Jews and Muslims from the rest of the world (Porteous 1979:30). Food is a symbol of one's culture, including religion (Fewell 1988:28).

Readers have an idea of the excellence and richness of royal food. That the young men renounced it for the sake of their loyalty towards Adonai, was the narrator's way of convincing readers in the 2 nd century $\mathrm{BCE}$, during the crisis caused by the Syrian king Antiochus IV Epiphanes, to stay faithful to $\mathrm{YHWH}$, because the tale assures them that $\mathrm{YHWH}$ will

12.Two modern examples of regime changes leading to ideological changing of significant names will suffice: the communists changing important names of cities and streets, and the present process in South Africa of name changes challenged by parts of minority groups.

13.De Bruyn (2014:12) suggests that Belshazzar means 'May Bel protect his life', Shadrach means 'The command of Aku', Meschach means 'Who is what Aku is', ( and Abednego means 'Servant of Nebo'. De Bruyn then concludes: 'With their new names, Daniel and his friends were cognitively inscribed [...] or re-proclaimed as vessels of the Babylonian gods. It meant that the four Judeans were no longer the property of Yahweh, but the property of the Babylonian gods.' This is not warranted by the grammatical uncertainty as to the meaning of the new Babylonian names ascribed to the four Jews. reward them in the end. 1 Maccabees 1:65-66 relates how the circumstances during Antiochus' persecution of the Jews forced them to eat unclean food. The righteous refused and they paid the highest price for their faithfulness.

Fewell (1991:18) reminds that the same verb is used to describe the giving of new names and the taking of food (Iוּנֶ, indicating that Daniel's intention was to limit the allconsuming process of indoctrination and subjection. That the chief officer allowed Daniel's experiment, was due to God disposing him to be kind and compassionate towards Daniel (Dn 1:9). The experiment succeeded and, without stating it, the readers understand that Adonai alone could have done this.

The food provided from the king's table could not harm the Judean men, whilst the vegetables and water the friends preferred could not guarantee that their appearance would be better and they would be fatter (Dn 1:15) after only 10 days. The implied reader would have understood that it was not the substance of the food and wine to which Daniel objected, but rather that Daniel expressed his dissent with the source of the food: the king and everything he stands for (Venter 2006:997-998). The food could not endanger Daniel's purity. What the food stood for, threatened the Jews' loyalty towards their God. Taking this food 'would be tantamount to declaring complete political allegiance' (Fewell 1988:40). Within a cognitive linguistic frameset, eating vegetables was a way for Daniel and his friends to set themselves apart as vessels through which YHWH could act inside of Marduk's god-space (De Bruyn 2014:12). Despite their new identities as symbolised by new names, Daniel and his friends refused to act as vessels of the Babylonian gods, but continued to act as YHWH's.

By choosing their own food, the four Jews created a personal space that allowed them to hold up their spiritual boundaries that kept their identity of purity and holiness intact. This way they retained some kind of personal control in a seemingly uncontrollable situation (Fewell 1988:40). Daniel's personal space was still controlled by his beliefs of purity and holiness when he did not allow the cultural-religious system of the physical space at the Babylonian court to invade his inner life (Venter 2006:997).

Israel set up rules and regulations for the Temple, sacrifices and worship that functioned as indicators of the boundaries of their identity, but the diaspora situation deprived them of their system of holiness and purity and had to be replaced by different measures, such as the study of the Torah and regulations determining their eating customs. In this way, exilic Jews could reclaim their religious and national identity, whilst keeping the delicate balance between opportunity and threat in a foreign land (Venter 2006):

In the historical situation in Babylonia with its specific sociological structures Daniel and his three associates are depicted as the heroes who could hold their own and even surpass others in success due to the personal space they created around themselves. (p. 1000) ${ }^{14}$

14.Venter (2006) utilises insights from Soja (1996) to discuss Daniel's food dilemma in terms of Firstspace, Secondspace and Thirdspace. 


\section{Daniel 1:17-21: The result of loyalty towards God}

God made the four Jews intelligent and proficient in all writings and wisdom, and gave Daniel understanding of visions and dreams of all kinds (Dn 1:17). ${ }^{15}$ The reason is that God rewards his servants' faithfulness (v. 11 indicates that the four friends also stay faithful to $\mathrm{YHWH}$ ). For the implied reader, wisdom has a specific association: of political ingenuity to explicate dreams, visions and apparitions, prediction of the future by way of astrology, the interpretation of signs and omens, the study of animals' intestines, and political acumen to advise a ruler or to rule (Sæbø 1997:420). This is in contrast to the wisdom literature presented in the Hebrew Bible, where didactic and reflective activities are indicated with 'wisdom'. Daniel's wisdom is political and mantic as in the Joseph and Esther tales (Brueggemann 1997:22).

The Babylonian king found the Jews 10 times better than

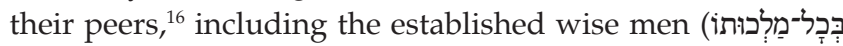

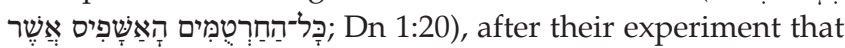
lasted 10 days (Dn 1:12,15). The Jews' reward was that they Istand before the king], referring to a slave standing before his master to do his will and execute his wishes (cf. 1 Sm 16:21; 1 Ki 12:6-8; Lk 1:19; Mt 18:10).

The only verb ascribed to God as subject is he gives (Dn 1:2, 9, 17) - a verb used the 5 th most in the Hebrew Bible and that indicates the process whereby an object or case is brought in movement (Labuschagne 1997:776). In this way the narrator demonstrates that Adonai determines history - and Daniel's life as a small part of it. Even when Daniel and his friends rebelled against the king's wishes, because they refused to swear loyalty towards another god, they were rewarded by the king with a foremost position at his court. The rebels, staying faithful to $\mathrm{YHWH}$, became the royal advisors. The irony is that they represented $\mathrm{YHWH}$ before the king and they furthered YHWH's interests, even though the king paid them to serve him with advice. What happened when the Babylonian king demanded fidelity from the four Jews? The question is answered in Daniel 3.

The tale ends as it starts, with Daniel and his friends placed in the royal court of Babylon. They were far from Jerusalem, destroyed by the Babylonian king, but at the court they represented what Jerusalem stood for: the Israelite temple and religious cult.

Daniel 1:21 relates that Daniel served at the court 'until the first year of king Cyrus', meaning that he survived the empire that imprisoned him. ${ }^{17}$ This verse sounds like an ironic snigger from heaven, when the Babylonian king trains Daniel to serve before him and Daniel stands in the end before the conqueror of the Babylonian empire, Cyrus

15 . With the exception of two terms indicating 'wisdom' in verse 4 , all the other terms used there are repeated in verse 17

16.'Ten times' is translated from 'ten hands', indicating that each of the Jews was equal to 10 hands, or five men (Wood 1973:46)

17.An analysis of the structure of Daniel 1 shows that the reference to time in Daniel 1:1 and 1:21 serves as inclusio of the tale.
(Veldkamp 1940:14). Daniel would have been in the service of the royal courts of several kings for 60 or 65 years, indicating that he would have been an old man by the time Cyrus was enthroned. This is not a problem for the narrator who wants to explain by the references to the various kings and empires that Daniel symbolised Jewish exile - from the time of Nebuchadnezzar who besieged Jerusalem and eventually burnt the city and its temple to the time of Cyrus. Daniel is painted as the figure that oppressed Jews could associate with. Daniel survived the empire that imprisoned him and shared in the edict of Cyrus announcing salvation for exilic Jews. He was a tower of strength and a star of hope for 2nd century Jews challenged by Antiochus' hellenising policies (King 1954:32). The Babylonian king trained Daniel to serve before his throne. Eventually Daniel served before the throne of the victor of the Babylonian king, showing the irony of the tale (Bultema 1988:58). ${ }^{18}$

\section{Space and power}

In the discussion of the different aspects of space utilised by the narrator, the link to the power play behind the narrative was demonstrated: between Judah as a defeated nation and the mighty Babylonian nation, the Jewish king being in prison in Babylon and the king ruling his royal court and the world, and Israel's God (who was seemingly defeated when his country was taken and his people removed from it) and Babylon's god triumphing over the exiles and their gods.

Power can be analysed in terms of metaphorical extension of basic bodily schemata, where humans give meaning to the space in which they live, and this meaning can be conceptualised in terms of their bodies. The schemata consisting of the field of movement, direction of action, levels of intensity and causal interaction is indicated by Venter (2006:1001-1002), utilising the insights of Johnson (1987:4748), as:

- Compulsion, forcing people in a direction.

- Blockage, where power is stopped and subjected or redirected.

- Counterforce, leading to direct confrontation.

- Diversion, when an opposing power forces diversion.

- Removal of restraint, when restriction to power is removed.

- Enablement, where people are manipulated due to a lack of opposition.

- Attraction, consisting of the ability to overpower others in one's own favour.

These actions contain the root meaning of force and barrier, where words like must, can and may play an important role.

Daniel's refusal to eat the royal food can be interpreted in these terms. His body is the container and to eat the king's food would imply taking food into this body that would disturb his loyalty towards his religious and national identity. Food becomes an external harmful power that 18.Daniel 1:21 contradicts 10:1, referring to the third year of Cyrus' reign, indicating the Daniel 1 may have functioned at an early stage apart from the rest of the book. 
should be prevented from contaminating their bodies. Should he partake in the food and wine, Daniel would allow it to become part of him, causing his world to come apart (Venter 2006:1002). Eating his own food becomes a measure against external powers entering his body and personal space, and he uses protection (see schemata above) to distance himself from the threat. Physical food does not threaten Daniel's physical body, but foreign ideology and religion threatens his mental body and idea world, and it should be averted at all cost. This lead to a direct confrontation where compulsive power is met with a counterforce in a display of power. The only reason why Daniel succeeds against the overpowering force of the foreign court is because his God gives favour and compassion to him in the sight of the Babylonian official.

Daniel 1 begins with an invasion of YHWH's space, but ends with a successful invasion of Nebuchadnezzar and/or Marduk's space by the God of Israel. By carrying YHWH's temple objects to the temple of his god, Nebuchadnezzar allows YHWH to invade Marduk's space (De Bruyn 2014:13).

YHWH protects Daniel and his friends within the profane world outside his territory. This implies that he will also protect his people within the profane world. YHWH's people need not fear the profane world, other nations or their gods who challenge YHWH's reign over the earth. Even the exile was caused by YHWH - he delivered his people into the hands of Nebuchadnezzar. When Antiochus IV profaned the Temple and killed the high priest, Onias III, in 171 BCE, it does not imply that the foreign king and his gods overpowered YHWH (cf. Dn 9:25-26; 10:25-26; Murphy 2002:158-161).

\section{Conclusion}

Daniel 1 serves as an introduction to the Book of Daniel and relates how Daniel and his friends were taken from Jerusalem and appointed as officials at the royal court in Babel. The narrative is determined by the various and significant references to space. The Jews' loyalty towards Jerusalem and its association with the Temple and temple cult, is challenged by the loyalty required from them at the Babylonian court as symbolised by the new names they receive. By refusing to eat specific foods set apart for the candidates, they create a space that relates to the determinative contrast between Jerusalem and Shinar. Reconstruction of ancient space was used to indicate how space determines and serves the sociohistoric background and ideology of the composition of Daniel 1, with references to a spatio-religious dimension, a social association of space, a religio-spatial distancing between Israel's and Babylon's religion, and Israel's God and Babylon's god and a wisdom dimension.

This article showed how space is utilised by the narrator to demonstrate the power play behind the narrative: between Judah as a defeated nation and mighty Babylon, the Jewish king in the prison in Babylon and the king ruling over his royal court, and Israel's God and Babylon's god.

\section{Acknowledgements Competing interests}

The author declares that he has no financial or personal relationship(s) that may have inappropriately influenced him in writing this article.

\section{References}

Abusch, T., 1995, 'Marduk', in K. van der Toorn, B. Becking \& P.W. van der Horst (eds.) Dictionary of deities and demons in the Bible, pp. 1014-1025, E.J. Brill, Leiden.

Anderson, R.A., 1975, Unfolding Daniel's prophecies, Pacific, Mountain View.

Anderson, R.A., 1984, Signs and wonders: A commentary on the Book of Daniel, Eerdmans, Grand Rapids. (International Theological Commentary).

Brueggemann, W., 1997, Cadences of home: Preaching among exiles, Westminster John Knox Press, Louisville.

Bultema, H., 1988, Commentary on Daniel, Kregel Publications, Grand Rapids.

Burden, J.J., 1993, 'Daniël', in W. Vosloo \& F. Janse van Rensburg (eds.), Die Bybel in praktyk, pp. 1221-1244, CUM, Vereeniging.

Charles, R.H., 1929, A critical and exegetical commentary on the Book of Daniel, Clarendon, Oxford.

Clarke, A., 1967, Adam Clarke's commentary on the Bible, abridged by R. Earle, Baker Book House, Grand Rapids.

Davies, P.R., 1985, Daniel: Old Testament Guides, JSOT Press, Sheffield.

De Bruyn, J.J., 2014, 'A clash of Gods - Conceptualizing space in Daniel 1', HTS Teologiese Studies / Theological Studies 70(3), Art. \#1956, 6 pages.

Fewell, D.N., 1988, Circle of sovereignty: A story of stories in Daniel 1-6, Almond, Sheffield. (JSOT Supplement Series 72).

Fewell, D.N., 1991, Circle of sovereignty: Plotting politics in the Book of Daniel, Abingdon, Nashville.

Hammer, R., 1976, The Book of Daniel, Cambridge University Press, Cambridge. (The Cambridge Bible Commentary).

Haspelmath, M., 1997, From space to time: Temporal adverbials in the world's languages, Lincom Europa, München, Newcastle.

Helberg, J.L., 1994, Die boek Daniël. Skrifuitleg vir Bybelstudent en gemeente, NG Kerkuitgewers, Kaapstad.

Hossfeld, F.L. \& Zenger, E., 2008, 'Psalm 137', in F-L. Lothar, E.A. Zenger \& K. Baltzer (eds.), Psalmen 101-150, pp. 684-703, Herder, Freiburg. (Herders Theologische Kommentar zum Alten Testament).

Humphreys, W.L., 1973, 'A life-style for diaspora: A study of the tales of Esther and David', Journal of Biblical Literature 92, 211-223. http://dx.doi. org $/ 10.2307 / 3262954$

Johnson, M., 1987, The body in the mind: The bodily basis of meaning, imagination, and reason, University of Chicago Press, Chicago.

Keil, C.F., 1975, Biblical commentary on the Book of Daniel, vol. 9, Eerdmans, Grand Rapids. (Commentary on the Old Testament in ten volumes).

King, G.F., 1954, Daniel: A detailed explanation of the book, The Midnight Cry, llford.

Koehler, L. \& Baumgartner, W., 1958, Lexicon in Veteris Testamenti Libros, E.J. Brill, Leiden.

Kühlewein, J., 1997, 'ba'al', in E. Jenni \& C. Westermann (eds.), Theological Lexicon of the Old Testament, transl. M.E. Biddle, vol. 1, pp. 247-251, Massachusetts, Peabody.

Labuschagne, C.J., 1997, 'ntn', in E. Jenni \& C. Westermann (eds.), Theological Lexicon of the Old Testament, transl. M.E. Biddle, vol. 2, pp. 774-791, Massachusetts, Peabody.

Levenson, J.D., 1984, 'The temple and the world', Journal of Religion 64, 275-298. http://dx.doi.org/10.1086/487131

Low, S.M. \& Lawrence-Zuniga, D., 2003, The anthropology of space and place: Locating culture, Blackwell, Malden.

Lucas, E.C., 2002, Daniel, Apollos/InterVarsity, Leicester/Downers Grove. (Apollos Old Testament Commentary 20).

Murphy, F.J., 2002, Early Judaism: The exile to the time of Jesus, Hendrickson, Peabody. Porteous, N., 1979, Daniel:Old Testament Library, 2nd rev. edn., SCM, London.

Sæbø, M., 1997, ' $\mathrm{hkm}$ ', in E. Jenni, E. \& C. Westermann (eds.), Theological Lexicon of the Old Testament, transl. M.E. Biddle, vol. 1, pp. 418-424, Massachusetts, Peabody.

Soja, E.W., 1996, Thirdspace: Journeys to Los Angeles and other real-and-imagined places, Blackwell, Oxford.

Sweeney, M.A., 2001, 'The end of eschatology in Daniel? Theological and sociopolitical ramifications of the changing contexts of interpretation', Biblical Interpretation 9(2), 123-140. http://dx.doi.org/10.1163/156851501300139273

Van Reeth, A., 1994, Ensiklopedie van die mitologie, transl. J. van Tonder, J. Combrinck \& D. Müller, Vlaeberg, Cape Town.

Veldkamp, H., 1940, Die knoopen ontbindt: Daniël, T. Wever N.V., Franeker. 
Venter, P.M., 2004, 'Constitualised space in Daniel 9', Hervormde Teologiese Studies 60(1-2), 607-624.

Venter, P.M., 2006, 'A study of space in Daniel 1', Old Testament Essays 19(3), 993-1004.

Wagner, M., 1997, 'qēș end', in E. Jenni \& C. Westermann (eds.), Theological Lexicon of the Old Testament, transl. M.E. Biddle, vol. 3, pp. 1153-1156, Hendrickson, Peabody.

Wansbrough, H. (ed.), 1985, The New Jerusalem Bible, Darton, Longman \& Todd, London.
Ward, J. \& Ward, C., 1995, Preaching from the prophets, Abingdon Press, Nashville. Wood, L., 1973, A commentary on Daniel, Zondervan, Grand Rapids.

Wouk, H., 1959, This is my God: The Jewish way of life, rev. edn., Doubleday, New York.

Zlatev, J., 2007, 'Spatial semantics', in D. Geeraets \& H. Cuyckens (eds.), The Oxford handbook of cognitive linguistics, pp. 318-350, Oxford University Press, Oxford. 